Available online at GSC Online Press Directory

GSC Biological and Pharmaceutical Sciences

e-ISSN: 2581-3250, CODEN (USA): GBPSC2

(RESEARCH ARTICLE)

\title{
Evaluation of WorldVeg rootstock lines for grafted tomato production in Uzbekistan
}

\author{
Karimov Bakhtiyor Akromovich ${ }^{1,}{ }^{*}$ and Mavlyanova Ravza Fazliddinovna ${ }^{2}$ \\ ${ }^{1}$ Junior Researcher, Laboratory of Vegetable Melon Crops Selection, Scientific Research Institute of Vegetable, Melon \\ Crops and Potato, Tashkent, Uzbekistan. \\ ${ }^{2}$ World Vegetable Center, Doctor of Agricultural Sciences, Coordinator of Central Asia and the Caucasus, Tashkent, \\ Uzbekistan.
}

Publication history: Received on 24 June 2019; revised on 07 August 2019; accepted on 14 August 2019

Article DOI: https://doi.org/10.30574/gscbps.2019.8.2.0115

\begin{abstract}
Tomato is consumed year-round in Central Asia. The crop is sown on a larger area than any other vegetable in the region, and tomato production levels exceed that of all other vegetables. However, local tomato varieties lack tolerance to biotic and abiotic stress. To address these concerns, the World Vegetable Center's (WorldVeg) tomato grafting technology was introduced and WorldVeg rootstock lines were evaluated in Uzbekistan. Grafting can help overcome some soil-borne diseases, flooding, and saline soils. Following WorldVeg's standard practices for grafting and cultivation, local variety Gulkand was grafted onto four rootstock lines with non-grafted Gulkand seedlings as the check. Experiment design was in four replications. Gulkand scions grafted onto three rootstocks flowered earlier (96-98 days) and ripened earlier (131-133 days) compared to the non-grafted Gulkand plants and treatment 1. Yield of non-grafted Gulkand plants from two harvests was $11.08 \mathrm{~kg} / \mathrm{m}^{2}$. All four grafted plants had a higher yield than the check. The highest yield at $116 \%$ was observed in treatment 2 . In comparison with the check fruit weight (109 g), heavier fruit (126-128 g) was observed in treatments 2 and 4. Plants in treatment 2 accumulated less nitrate nitrogen than the check. Nitrate nitrogen levels were slightly higher in treatment 1 . Based on these indicators, treatments 2 and 4 were the best performers, characterized by strong plant development, high yield and fruit weight. Treatments 1 and 2 showed the highest accumulation of chemical content in tomato fruit. Lines in treatments 1,2 and 4 are recommended as rootstocks for tomato grafting.
\end{abstract}

Keywords: Tomato; Scion; Rootstock; Grafting; Yield; Chemical composition

\section{Introduction}

Vegetable production around the world is increasingly hampered by abiotic constraints such as drought, extreme temperature, salinity, flooding, low nutrients, organic and heavy metals contamination, as well as the biotic stresses of soil- and air-borne pests and diseases. This situation is aggravated by successive cropping, environmental policies such as the phase-out of chemical soil disinfectants, and negative impacts of climate change [1].

Grafting is a promising method to overcome some of these constraints to increase productivity and improve fruit quality. Grafting is the binding of a cutting (the scion, the aboveground stem and leaves) of one plant to another (the rootstock, the lower stem and roots). Rootstocks must be able to form a strong root system, tolerate heat, drought, and soil salts, and have genetic resistance to various pathogens. Vegetable grafting for tomato, pepper, eggplant, cucumber, melon and other crops has proven to be effective in various countries [2].

Grafting is widely used for various vegetable crops in Europe and Asia. For example, 81\% of Korean vegetables and 54\% of all Japanese vegetables (95\% of Japan's watermelon, oriental melons, greenhouse cucumber, tomato and eggplant)

\footnotetext{
${ }^{*}$ Corresponding author

E-mail address: agrobiotechinfo@yandex.ru
} 
are produced on grafted plants [3]. About $40 \%$ of watermelon, $20 \%$ of melon, $30 \%$ of cucumber, $15 \%$ of eggplant, $1 \%$ of tomato, and $1 \%$ of pepper are grafted in China. Vegetable grafting is popular throughout Europe, especially in Greece, Spain, France and Italy. It is also practiced in Morocco. Grafting can help growers avoid blossom end-rot, a physiological disorder caused by low calcium levels [4].

Scion/rootstock production methods and grafting techniques are described in detail in the World Vegetable Center's International Cooperators' Guide [5].

Grafting tomato scions and eggplant rootstocks increased yields by 20 to $100 \%$ compared to non-grafted plants in field trials conducted in the Philippines and Vietnam. Studies in the Philippines indicated that grafted tomato plants outyielded non-grafted plants by $41 \%$ under simple plastic rain shelters and by $20 \%$ in the open field [6].

There is increasing interest in using novel rootstocks to confer resistance to abiotic stresses in horticultural species, and to understand the physiological mechanisms conferring these responses. Grafting provides a rapid and direct means to transfer rootstock-mediated abiotic stress tolerance to commercial stress-sensitive cultivars. Nutrient deficiency is a widespread problem in some soils, inhibiting physiological processes and thus reducing crop yield [7].

Grafting can enhance the tolerance of vegetable crops to soil-borne pathogens and is an effective method to reduce losses from bacterial wilt and to sustain marketable yield [8]. The availability of numerous rootstocks for tomato has increased the plant host variability and thus the interaction with pathogens [9].

Grafting appears to be useful for increasing the tolerance of vegetable crops to toxic elements, and for preventing the entry of contaminants and saline compounds into the human food supply [10].

The United Nations Industrial Development Organization recommended phasing out methyl bromide for soil fumigation and suggested grafting and soil solarization combined with metam sodium as an alternative approach; this method has been found effective in several countries [11].

At high selling prices, growers can afford to pay price premiums for grafted transplants because only very modest yield improvements are required to compensate for the higher costs of grafted plants. Use of grafted plants has the potential to generate economic benefits in all systems, but the actual outcome is dependent on multiple factors [12].

In Uzbekistan, tomato is a leading species among vegetable crops. Tomato is grown in the open field on an area of more than 50,000 hectares; in greenhouses, tomatoes are grown on an area of 4,500 hectares. Local tomato varieties have good fruit shape, color and taste. However, the yield and fruit quality of tomatoes grown in greenhouses in the winter is generally poor, due to low soil and air temperatures, lack of light, and diseases including Fusarium wilt. Grafting can help greenhouse growers overcome disease problems. Until recently, tomato grafting was relatively unknown in Uzbekistan and suitable tomato rootstocks were not available. We studied tomato lines to select promising rootstocks to increase yield and fruit quality in greenhouses

\section{Material and methods}

Experiments were conducted in a greenhouse on the experimental farm of Tashkent State Agricultural University in two seasons, winter and spring. Research was conducted according to protocols in Guidelines for the study of the tomato world collection of VIR [13] and instructions for tomato grafting [14] and [15]. Standard greenhouse cultivation practices for tomato were followed.

Locally bred tomato variety Gulkand was the check in our experiments. Developed by the Research Institute of Vegetable, Melon Crops and Potato, Gulkand is suitable for greenhouse production. The variety is mid-maturing (135 days) and semi-indeterminate $(2.0 \mathrm{~m})$. Fruits are round-shaped, pointed at the top, rose-red in color, and average fruit weight is $110 \mathrm{~g}$. Gulkand is not resistant to Tomato mosaic virus or Fusarium wilt.

Four tomato lines introduced from AVRDC - The World Vegetable Center Taiwan were studied as rootstocks. One line, LBR17, was introduced from the AVRDC Breeding Unit and three others were from the AVRDC Mycology Unit. Two of the tomato lines were wild relatives of tomato (Solanum pimpinellifolium).

Seed of the four lines and Gulkand were sown in trays at the end of October. A heating system was used in the greenhouse in winter; air temperature ranged from $22-26^{\circ} \mathrm{C}$ during the day and from $17-22{ }^{\circ} \mathrm{C}$ at night. Monitoring 
and observation was done during the sprouting and early growth of the seedlings. Data collected included the number of days from sowing to sprouting, the appearance of the first and second leaves, and the diameter and height of the stem in the first and second leaf phases.

Gulkand was grafted onto the four lines when the plant had 2-3 true leaves and the stem diameter was 1.6-2.0 mm. The combination of scion (Gulkand) and rootstocks (line/accessions) was as follows: treatment 1 (Gulkand + LBR17); treatment 2 (Gulkand + L03708); treatment 3 (Gulkand + L05983) and treatment 4 (Gulkand + L06193). Non-grafted Gulkand was used as the check.

The experiment was laid out in a randomized complete block design with 4 replications, with 10 plants in each replication. Seedlings were planted in a single row $70 \times 40 \mathrm{~cm}$ in length. There were narrow paths separating the rows. Protective rows of tomato $(70 \times 40 \mathrm{~cm})$ were planted along the edges of the experiment. Observations were carried out during the growing season for $10 \%$ and $75 \%$ seed germination after sowing; emergence of the first and second true leaves; and $10 \%$ and $75 \%$ of fruit maturing. Stem, leaves, bush and fruit were measured. The presence of plant diseases and pests was determined by visual inspection. Degree of susceptibility and prevalence of disease was calculated. Yield was harvested from all plants of each plot, then marketable and non-marketable fruits were weighed at each harvest. Total yield in $\mathrm{kg} / \mathrm{m}^{2}$ was calculated.

Biochemical analysis of fruits was carried out at fruit ripening. The content of dry matter was analyzed by dry weight, sugar content (Bertrand method), ascorbic acid and carotene (Murry method), the amount of organic acids in terms of malic acid by coulometric titration (Petersburgskii method), nitrate nitrogen (Vdovina-Medvedeva method), and the use of ion-selective electrodes. Statistical analysis of the results was carried out following Dospekhov [16].

\section{Results and discussion}

\subsection{Optimal diameter and height of the tomato rootstock and scion for grafting}

Accessions varied in stem diameter and stem height during first and second leaf phases (Table 1). Stem diameter and length of all four lines were appropriate for grafting with Gulkand.

Table 1 Diameter and height of tomato seedling stems

\begin{tabular}{|c|c|c|c|c|}
\hline \multirow[t]{2}{*}{ Entry } & \multicolumn{2}{|c|}{ Phase: first leaf } & \multicolumn{2}{|c|}{ Phase: second leaf } \\
\hline & $\begin{array}{l}\text { Stem diameter, } \\
\text { cm }\end{array}$ & $\begin{array}{l}\text { Stem height, } \\
\text { cm }\end{array}$ & Stem diameter, $\mathrm{cm}$ & Stem height, cm \\
\hline Gulkand & 0.09 & 3.3 & 0.13 & 3.9 \\
\hline LBR17 & 0.11 & 3.1 & 0.14 & 3.7 \\
\hline L03708 & 0.09 & 3.1 & 0.12 & 3.6 \\
\hline L05983 & 0.12 & 3.2 & 0.14 & 3.7 \\
\hline L06193 & 0.09 & 3.3 & 0.13 & 3.9 \\
\hline Mean & 0.10 & 3.20 & 0.13 & 3.76 \\
\hline $\mathrm{LCD}_{05}$ & 1.12 & 1.13 & 1.12 & 1.13 \\
\hline $\mathrm{CV}, \%$ & 28.67 & 8.06 & 19.85 & 5.73 \\
\hline
\end{tabular}

The average diameter of the stem in the phase of the second leaf was $0.13 \mathrm{~cm}$ and the average height of the plants was $3.76 \mathrm{~cm}$. Stem diameters of treatments LBR17 and L05983 were significantly higher than treatments L03708 and L06193. Their stem diameter was less, since these were grafted onto S. pimpinellifolium rootstocks. Plant height for all treatments was below average. However, height is not essential for grafting and its variability was low $(\mathrm{CV}=5.73 \%)$.

To prepare seedlings for grafting, growers should take into account the diameter of the stem to ensure compatibility of scion and rootstock. When using local tomato varieties for grafting that demonstrate rapid stem and diameter growth, sowing should be done 3-4 days later than for rootstocks with smaller stem diameters (wild species). 


\subsection{Tomato greenhouse trial}

\subsubsection{Phenological observation}

Plants of treatments 2, 3 and 4 were characterized by early flowering and ripening, compared with non-grafted Gulkand and treatment 1 (Table 2).

Table 2 Phenological observations of Gulkand grafted on rootstocks

\begin{tabular}{|c|c|c|c|c|c|}
\hline Entry & $\begin{array}{l}\text { Beginning } \\
\text { flowering } \\
(10 \%)^{a} \text {, days }\end{array}$ & of & $\begin{array}{l}\text { Flowering } \\
(75 \%)^{a} \text {, days }\end{array}$ & $\begin{array}{l}\text { Beginning of fruit } \\
\text { ripening } \\
\text { days }\end{array}$ & $\begin{array}{l}\text { Fruit ripening } \\
(75 \%)^{a} \text {, days }\end{array}$ \\
\hline Gulkand (check) & 94 & & 101 & 129 & 136 \\
\hline Treatment 1 & 95 & & 103 & 130 & 138 \\
\hline Treatment 2 & 90 & & 98 & 125 & 133 \\
\hline Treatment 3 & 91 & & 98 & 126 & 133 \\
\hline Treatment 4 & 90 & & 96 & 125 & 131 \\
\hline
\end{tabular}

Visual inspection revealed all grafted plants were susceptible to Tobacco mosaic virus, leaf mould (Cladosporium falirum Cocke), and Fusarium wilt (F. oxysporum). The check Gulkand was affected by Tobacco mosaic virus (10\% of plants), brown leaf spot (2\%) and Fusarium wilt (10\%).

\subsubsection{Yield}

Gulkand yielded $11.08 \mathrm{~kg} / \mathrm{m}^{2}$. Yield from the four treatments exceeded the check. Treatments 1 and 3 had the highest yield. The highest yield exceeding the check by 103-116\% was in treatments 2 and 4, respectively (Table 3). Plants of treatments 2 and 4 grafted on $S$. pimpinellifolium had longer main stems (up to $3.8 \mathrm{~m}$ ), a larger number of internodes, and a larger number of fruits in the cluster (5.0-5.2). The check had a stem length of $2.4 \mathrm{~m}$ and 4.4 fruits in the cluster.

Table 3 Yield of Gulkand (check) and Gulkand grafted on rootstocks

\begin{tabular}{lllll}
\hline Entry & $\begin{array}{l}\text { Total yield } \\
\mathbf{k g} / \mathbf{m}^{2}\end{array}$ & $\begin{array}{l}\text { Increasing } \\
\text { check \% }\end{array}$ & $\begin{array}{l}\text { the } \\
\mathbf{\%}\end{array}$ & $\begin{array}{l}\text { Marketability } \\
\text { Average fruit } \\
\text { mass g }\end{array}$ \\
\hline Gulkand (check) & 11.08 & 0 & 92 & 109 \\
Treatment 1 & 14.06 & +27 & 87 & 121 \\
Treatment 2 & 23.99 & +116 & 91 & 128 \\
Treatment 3 & 13.69 & +24 & 99 & 115 \\
Treatment 4 & 22.54 & +103 & 91 & 126 \\
Mean & 17.07 & & & 119.80 \\
LCD 05 & 1.18 & & & 2.32 \\
CV,\% & 33.26 & & & 11.22 \\
\hline
\end{tabular}

Fruit weight of all treatments was more than the check. In comparison with the check, treatments 2 and 4 had higher fruit weight (126-128 g). Average yield was $17.07 \mathrm{~kg} / \mathrm{m}^{2}$ and average fruit weight was $119.80 \mathrm{~g}$. Treatments 2 and 4 were significantly for yield and average fruit weight. The coefficient of the variation showed significant variability in total yield (CV $=33.26 \%)$ and fruit weight $(\mathrm{CV}=11.22 \%)$.

\subsubsection{Chemical composition}

Chemical composition of fruit showed differences depending on the rootstock used. Dry matter, soluble dry matter, and ascorbic acid were highest in treatments 1 and 2 . The sum of organic acids was higher in treatment 3 and 4 . Treatments 
2 had the lowest accumulation of nitrate nitrogen. Fruits of treatments 3 and 4 accumulated somewhat more nitrate nitrogen than the other treatments, but within permissible rates (Table 4).

Table 4 Chemical composition of fruit of Gulkand grafted on rootstocks

\begin{tabular}{llllll}
\hline Matters & Gulkand (check) & Treatment 1 & Treatment 2 & Treatment 3 & Treatment 4 \\
\hline Solid matter, \% & 6.4 & 6.5 & 6.6 & 6.3 & 6.2 \\
Soluble matter, dry, \% & 6.0 & 6.1 & 6.2 & 5.8 & 5.7 \\
Sugar, \% of fruit fresh weight: & & & & \\
Common & 3.80 & 3.86 & 3.95 & 3.60 & 3.50 \\
Monosaccharide & 3.60 & 3.66 & 3.70 & 3.30 & 3.20 \\
Saccharose & 0.18 & 0.22 & 0.23 & 0.28 & 0.26 \\
Sum of organic acids, mg/kg & 0.54 & 0.52 & 0.50 & 0.59 & 0.62 \\
Ascorbic acid, mg/kg & 23.9 & 24.1 & 24.8 & 21.8 & 20.9 \\
Nitrate nitrogen, $\mathrm{mg} / \mathrm{kg}$ & 38.1 & 40.8 & 37.4 & 44.4 & 41.8 \\
\hline
\end{tabular}

\section{Conclusion}

There are differences in development phases, yield, fruit weight and chemical composition of grafted and non-grafted tomato plants grown in greenhouses in Uzbekistan. Non-grafted Gulkand matured later compared to treatments 2, 3 and 4. Treatments 2 and 4 were characterized by good development of plants, high yield (exceeding the check by 103$116 \%$, respectively) and average fruit weight (126-128 g, respectively). Treatments 1 and 2 had high chemical content. Lines in treatments 1,2 , and 4 are thus recommended as promising rootstocks for use in further research, breeding and production. This research helped to lay the foundations for the development of tomato grafting as a sustainable method to increase the productivity and quality of tomato grown in Uzbekistan.

\section{Compliance with ethical standards}

\section{Acknowledgments}

The authors acknowledge the laboratory staff of Department of Vegetable, Melon Crops Selection, Scientific Research Institute of Vegetable, Melon Crops and Potato, Tashkent, Uzbekistan.

\section{Disclosure of conflict of interest}

No conflict of interest declared.

\section{References}

[1] Colla G, Schwarz D and Perez-Alfacea F. (2017). Vegetable grafting principles and practices. CABI, 298.

[2] Cassaniti C, Giuffrida F, Leonardi C, Causarano G, Marcellino F, Longombardo S and Tumino V. (2015). Lateral stem development in tomato according to rootstock vigour and seedling management practices. Acta Hortic. 1086:205-211.

[3] Introducing our first crop ever of grafted tomatoes! Garden News. \#33 (June 2, 2010).

[4] Huang Y, Kong QS, Chen F and Bie ZL. (2015). The history, current status and future prospects of vegetable grafting in China. Acta Hortic. 1086, 31-39.

[5] Black LL, Wu DL, Wang JF, Kalb T, Abbass D and Chen JH. (2003). Grafting Tomatoes for Production in the HotWet Season. International Cooperators Guide. AVRDC pub 03-551, 6.

[6] Palada MC and Wu DL. (2010). Grafting techniques for tomato and pepper under rice-based cropping system. In: IPM in vegetables: enhancing its implementation in rice-based cropping systems. (Metro Manila: Department of Agriculture - Bureau of Agricultural Research), 91-123. 
[7] Albacete A, Andújar C, Dodd I, Giuffrida F, Hichri I, Lutts S, Thompson A and Asins M. (2015). Rootstock-mediated variation in tomato vegetative growth under drought, salinity and soil impedance stresses. Acta Hortic. 1086, 141-146.

[8] Suchoff D, Gunter C, Schultheis J and Louws FJ. (2015). On-farm grafted tomato trial to manage bacterial wilt. Acta Hortic. 1086, 119-127.

[9] Polizzi G, Guarnaccia V, Vitale A, Marra M, Rocco M, Arena S, Scaloni A, Giuffrida F, Cassaniti C and Leonardi C. (2015). Scion/rootstock interaction and tolerance expression of tomato to FORL. Acta Hortic. 1086:189-194.

[10] Edelstein M and Ben-Hur M. (2015). Grafting: a useful tool to increase tolerance to toxic elements in vegetables under arid and semiarid conditions. Acta Hortic. 1086, 133-140.

[11] UNIDO. Phasing - out of methyl bromide in horticulture of Romania. Progress report: May 2003 to March 2004.

[12] Rysin O, Rivard C and Louws FJ. (2015). Is vegetable grafting economically viable in the United States: evidence from four different tomato production systems. Acta Hortic. 1086, 79-86.

[13] Guidelines for the study of the tomato world collection. (1977). Leningrad, 14-19.

[14] Oda M. (1999). Grafting of vegetables to improve greenhouse production. Food \& Fertilizer Technology Center Extension Bulletin 480, 1-11.

[15] Black L, Wu D, Wang J, Kalb T, Abbass D and Chen J. (2003). Grafting tomatoes for production in the hot-wet season. Asian Vegetable Research \& Development Center. AVRDC Publication (03-551), 6.

[16] Dospekhov BA. (1985). Field Experience methods. 5th edition. Moscow: Agropromizdat, 49-69.

\section{How to cite this article}

Karimov BA and Mavlyanova RF. (2019). Evaluation of WorldVeg rootstock lines for grafted tomato production in Uzbekistan. GSC Biological and Pharmaceutical Sciences, 8(2), 95-100. 